\title{
Seasonal dynamics of prairie sandreed rhizome development
}

\author{
PATRICK E. REECE, JENNIFER S. NIXON, LOWELL E. MOSER, AND STEVEN S. WALLER
}

Authors are Professor, University of Nebraska, Panhandle Research and Extension Center, 4502 Avenue Scottsbluff, Nebr. 69361; Extension Educator, Sioux County Extension, 325 Main, Harrison, Nebr. 69346; Professor, Dept. of Agronomy, 352 Keim Hall, University of Nebraska, Lincoln, Nebr. 68583; Associate Dean, 103 Agricultural Hall, University of Nebraska, Lincoln, Nebr. 68583.

\begin{abstract}
Multiple generations of rhizome-connected tillers stabilize soils and produce measurable amounts of herbage on sandy rangeland throughout the world. However, little is known about the dynamics of rhizome development in these clonal plant species. Seasonal relationships between foliar characteristics and rhizomes of prairie sandreed [Calamovilfa longifolia (Hook) Scribn.] were examined on sands range sites at 30-day intervals from May through September 1989 and 1990 at the University of Nebraska, Panhandle Experimental Range near Scottsbluff. Quadrats were excavated each year from two, 5 x 5 Latin Square macroplots in each of 2 grazing histories, long-term rest or current-year deferment. Under dry conditions in 1989 , a $65 \%$ reduction in the length of new rhizomes during July preceded a $64 \%$ reduction in live tillers in August. After which, rhizome length and live tiller density were unchanged and mean tiller weight increased during September. When average precipitation occurred in 1990, a $25 \%$ reduction in live tillers and concurrent increases in new rhizome length and mean tiller weight occurred during July. Rhizome bud densities increased throughout the growing season at different but predictable rates $\left(R^{2} \geq 0.95\right)$ for grazing histories, regardless of precipitation. Length of new rhizomes was highly correlated $\left(R^{2}=0.91\right)$ with live herbage throughout the growing season. Measurable increases in total rhizome length did not occur until live herbage of prairie sandreed exceeded a threshold of about $50 \mathrm{~g} \mathrm{~m}^{-2}$. Maximum increase in length of new rhizomes per unit of live herbage was about $10 \mathrm{~cm} \mathrm{~g}^{-1}$ near $100 \mathrm{~g} \mathrm{~m}^{-2}$. Given its dependence on vegetative reproduction and relatively high palatability to beef cattle, periodic or repeated years of full growing season deferment may be the only reliable method of obtaining measurable increases in prairie sandreed populations.
\end{abstract}

Key Words: Calamovilfa longifolia, warm-season grass, clonal growth, reproduction threshold, tiller dynamics

Published as Paper 12924 Journal Series, Nebraska Agricultural Research Division. The authors wish to thank Gordon Moeller, Jay and Gretchen Lees, Myron Riggs, Mick Friemuth, Jack Alexander, Lori Williams, Maureen Skavdahl, Mollie Reece, Bill Goodwin, Hazel Fritschen, Laurie Baker, Echo Fisher, Cheryl Bolen, and Paige Wolken for the many hours they invested in excavating and processing samples. We would also like to express our appreciation to Sharon Holman for the preparation of the manuscript and to Ann Koehler for preparation of the graphics.

Manuscript accepted 20 Jul. 01.
Resumen

Generaciones múltiples de hijuelos conectados por rizomas estabilizan los suelos y producen cantidades medibles de forraje en los pastizales arenosos del mundo. Sin embargo, poco se conoce respecto a las dinámicas de desarrollo de los rizomas en estas especies vegetales clonales. Se examinaron la relaciones estacionales entre las características foliares y los rizomas del zacate "Prairie sandreed" [Calamovilfa longifolia (Hook) Scribn.]; el estudio se llevo a cabo en la Estación Experimental de Pastizales Panhandle de la Universidad de Nebraska, cerca de Scottbluff, y se realizó en sitios de pastizal arenosos en intervalos de 30 días de Mayo a Septiembre de 1989 a 1990. Cada año se excavaron cuadrantes en dos macro parcelas de un Cuadro Latino 5 x 5 situadas en dos áreas con diferente historial de manejo del apacentamiento, descanso a largo plazo y diferimiento del año actual. En 1989, bajo condiciones de sequía, una reducción del $65 \%$ de la longitud de los nuevos rizomas registrada en Julio precedió a una reducción del $64 \%$ de los hijuelos vivos registrada en Agosto. Después de la cual, la longitud de los rizomas y la densidad de los hijuelos vivos permanecieron sin cambio y la media de peso de los hijuelos se incrementó durante Septiembre. En 1990, año con precipitación promedio, en Julio se observó un $25 \%$ de reducción en los hijuelos vivos e incrementos concurrentes de la longitud de los rizomas nuevos y la media de peso de los hijuelos. Las densidades de yemas de hijuelos se incrementaron a través de la estación de crecimiento a diferentes tasas ( pero predecibles) $\left(R^{2}>0.95\right)$ para las historias de apacentamiento, sin importar la precipitación. A lo largo de la estación de crecimiento la longitud de los nuevos rizomas estuvo altamente correlacionada $\left(R^{2}=0.91\right)$ con el forraje vivo. No ocurren incrementos medibles en la longitud total de los rizomas hasta que el forraje vivo del "Prairie sandreed" excedió un umbral de aproximadamente $50 \mathrm{~g} \mathrm{~m}^{-2}$. El máximo incremento de la longitud de los rizomas nuevos por unidad de forraje vivo fue aproximadamente de $10 \mathrm{~cm} \mathrm{~g}^{-1}$ casi $100 \mathrm{~g} \mathrm{~m}^{-2}$. Dada su dependencia en la reproducción vegetativa y su gustocidad relativamente alta para el ganado para carne, el diferimiento periódico o repetido de la estación de crecimiento completa puede ser el único método confiable para obtener incrementos medibles en poblaciones de "Prairie Sandreed".

The relative value of rhizomes in reproduction, resource acquisition, and interactions among rhizome-connected shoots has been reported for graminoid (Hartnett 1989, Jónsdóttir and Callaghan 1990, Jónsdóttir 1991, de Kroon et al. 1992, Wikberg et al. 1994, Makita 1996) and forb (Hartnett 1990, Hara and 
Wakahara 1994, Schmid et al. 1995) species. However, most of this information is limited to end-of-season measurements. Field studies of grass rhizome dynamics during the growing season are rare (Brejda et al. 1989) and quantification of seasonal relationships between rhizome and shoot characteristics during the growing season has not been reported.

Networks of rhizome-connected tillers are highly effective in stabilizing sandy soils in the Nebraska Sandhills, the largest stabilized sand dune formation in the western hemisphere encompassing about 4.9 million ha. Prairie sandreed [Calamovilfa longifolia (Hook) Scribn.] is a co-dominant, warm-season, rhizomatous grass in mid- to late seral plant communities on all upland sites in the Sandhills and on many sandy range sites in the northern Great Plains of USA and Canada (GPFA 1986). Prairie sandreed tillers develop almost exclusively from buds at the distal end of rhizomes which are unbranched and relatively long and deep compared to other plant species in the Sandhills (Brejda et al. 1989, Nixon 1993, Hendrickson et al. 1998).

Our primary objective was to quantify seasonal relationships between prairie sandreed shoot and rhizome characteristics in natural plant communities. Excavation macroplots were also blocked by grazing history and protected from defoliation to evaluate seasonal dynamics of rhizome development after more than 14 years of rest compared to a single year of full growing season deferment. Based on preliminary field evaluations, we hypothesized that length of new rhizomes within a given soil volume increases monotonically as live herbage of prairie sandreed increases within the sample area during the growing season. We further hypothesized that the rate of change in rhizome length per unit change in herbage is independent of grazing history.

\section{Materials and Methods}

The study was conducted during 1989 and 1990 at the University of Nebraska, Panhandle Experimental Range (PER, $42^{\circ}$ $\left.08^{\prime} \mathrm{N}, 103^{\circ} 43^{\prime} \mathrm{W}\right), 19 \mathrm{~km}$ northwest of Scottsbluff, Nebraska. Soils are Valent fine sands (Mixed Mesic Ustic Torripsamment). About $73 \%$ of annual precipitation occurs during the growing season from May to September. Longterm average annual precipitation was 340 mm with $270 \mathrm{~mm}$ in 1989 and $350 \mathrm{~mm}$ in 1990. Rangelands in mid- to late seral stages at this location are dominated by prairie sandreed. Other abundant species include needleandthread (Stipa comata Trin. \& Rupr.), blue grama [Bouteloua gracilis (HBK) Lag. ex Griffiths], and sand dropseed [Sporobolus cryptandrus (Torr.) A. Gray]. Sand bluestem (Andropogon halli Hack.) is abundant in late seral stages (GPFA 1986).

Four macroplots with uniform distribution of prairie sandreed tillers were selected in a 5.0-ha exclosure constructed in 1974 and in the pasture where the exclosure was located. The pasture had been moderately stocked at 1.0 AUM ha ${ }^{-1}$ and continuously grazed from May through September since 1978. Two macroplots within each grazing history were randomly selected for excavation in each year. Fences were constructed to exclude cattle from 2 previously grazed macroplots in the pasture in April each year. A $5 \times 5$ grid of $0.5-\mathrm{m}^{2}$ quadrats $(0.71 \times 0.71 \mathrm{~m})$ with $0.71-\mathrm{m}$ wide alleys was marked on selected macroplots in April 1989 and 1990. Excavation dates were assigned to quadrats within rows and columns according to randomization procedures for Latin Squares. Five quadrats were excavated to a depth of $30 \mathrm{~cm}$ from 2 macroplots in the long-term-rested area and 2 macroplots in the current-year-deferred areas at 30-day intervals from 30 May to 30 September in 1989 and 1990. Prairie sandreed plants were separated from soil and other plant material over wire screens at the excavation site, bagged, and transported on dry ice to freezers.

Plant material was separated into live shoots, crowns, rhizome buds, new rhizomes, and old rhizomes. Initially rhizomes grow horizontally from the point of origin followed by vertical growth which culminates in the development of a shoot if the rhizome is not aborted. Rhizomes originate from buds nears the base of vertical crowns. Rhizome buds were differentiated and visually discernable shoots less than 2-cm long. Buds elongating beyond 2 $\mathrm{cm}$ were classified as new rhizomes. New rhizomes had numerous, light tan, intact exterior scales. Rhizomes in this category formed connections between crowns of current-year and/or prior-year shoots or they originated from a shoot and had not emerged. Old rhizomes were dark tan to black with no scales or low densities of fractured scales. Length of rhizomes was measured by hand. Intact networks of old rhizomes often connected 6 to 8 crowns. Plant components were oven dried at $50^{\circ} \mathrm{C}$ to a constant weight. Mean tiller weights were calculated from total weight of live herbage and density of live tillers within each excavated area.

The average laboratory time required to separate prairie sandreed from a single 0 . $5-\mathrm{m}^{2}$ quadrat into plant components in 1989 was 3.5 hours. During August and September 1989, the quarter of the quadrat with the density of live prairie sandreed tillers most similar to the average for the entire $0.5 \mathrm{~m}^{2}$ quadrat was excavated separately. Variances and means for quarter and full quadrat data sets were similar based on $\mathrm{F}$ and $\mathrm{t}$-tests at $\mathrm{P} \leq 0.05$. In 1990 , the area of excavated experimental units was reduced to $35 \times 35 \mathrm{~cm}$, the quarter with a tiller density most similar to the original $0.5 \mathrm{~m}^{2}$ quadrat.

Data were analyzed as a Latin Square using old rhizome length as a linear covariate with the General Linear Models Procedure (SAS 1986). Experimental units were individual quadrats within Latin Square macroplots, blocked by grazing history. Season and season by year interaction effects with grazing history were tested. However, comparisons of means for grazing histories were not valid without replication which was precluded by labor constraints. The Least-Squares Means Procedure within SAS was used for mean separation among excavation dates (Searle et al. 1980). Treatment effects were reported as significant at $\mathrm{P} \leq 0$. 10 . Values used to compute regression equations (SAS 1986) for seasonal changes in density of differentiated rhizome buds below crowns on long-term-rested and current-year-deferred macroplots were the means of 20 excavated quadrats. Values used to compute regression equations for the relationships between the length and weight of new prairie sandreed rhizomes and between live prairie sandreed herbage and the length of new rhizomes were the means of 10 excavated quadrats.

\section{Results and Discussion}

Dormant season precipitation from 1 October to 30 April was $42 \%$ of long-term average before the 1989 growing season compared to $129 \%$ before the 1990 growing season (Fig. 1). Peak standing herbage is highly correlated with the quantity of moisture in Valent soils in mid-April (Dahl 1963). Additionally, total herbage production per unit of spring soil moisture is about 58 and $167 \%$ greater than for soil moisture received during early and late summer, respectively (Dahl 1963). While precipitation during June was only $5 \%$ of the long-term average in 1989 and $23 \%$ in 


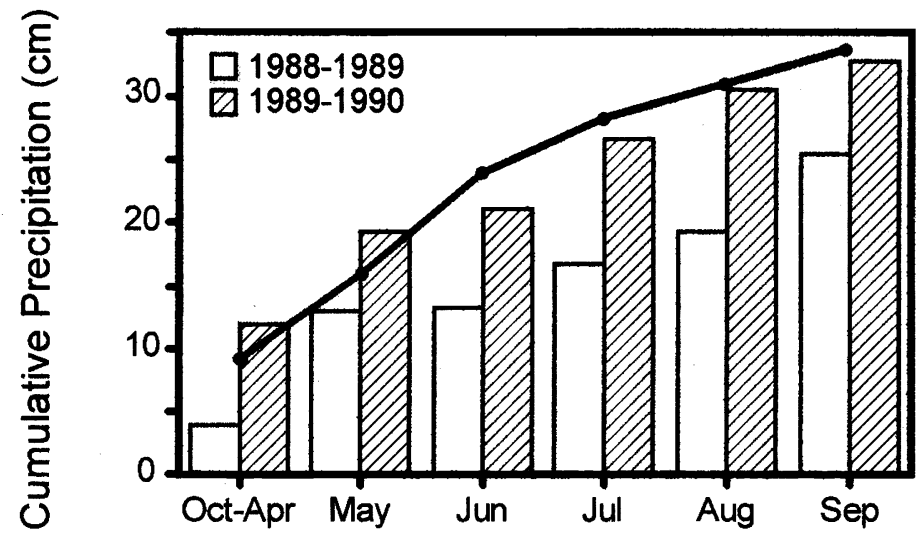

Fig. 1. Cumulative annual precipitation from 1 Oct. to 30 Sept. for the 1989 and 1990 growing seasons and the 30-year average $(\bullet-\bullet)$ at the University of Nebraska, Panhandle Experimental Range near Scottsbluff, Nebr.

1990, cumulative precipitation beginning in October 1989 was similar to the 30-year average during most of the 1990 growing season because of above average precipitation during the preceding dormant season. Cumulative precipitation beginning in October 1988 was about $10 \mathrm{~cm}$ below the 30-year average from 1 June to 31 August 1989 , the primary growing season for prairie sandreed (Fig. 1).

\section{Tillers}

Regardless of precipitation regime or grazing history, measurable declines in the density of live prairie sandreed tillers occurred during each growing season (Table 1). Densities of live tillers declined by about $64 \%$ on all macroplots during August 1989 and about 25\% during July 1990 (Table 1). Similar changes in live tiller density for grazing histories in both

Table 1. Mean density and weight of live prairie sandreed tillers for grazing histories from May through September 1989 and 1990 at the University of Nebraska, Panhandle Experimental Range near Scottsbluff, Nebr.

\begin{tabular}{lcccc}
\hline \hline & \multicolumn{2}{c}{1989} & & 1990 \\
\cline { 2 - 3 } Date & $\begin{array}{c}\text { Current-year- } \\
\text { deferred }\end{array}$ & $\begin{array}{c}\text { Long-term- } \\
\text { rested }\end{array}$ & $\begin{array}{c}\text { Current-year- } \\
\text { deferred }\end{array}$ & $\begin{array}{c}\text { Long-term- } \\
\text { rested }\end{array}$ \\
\hline & & Tiller Density & (no. $\left.{ }^{-2}\right)$ & \\
May 30 & $169 \mathrm{a}$ & $262 \mathrm{a}$ & $139 \mathrm{ab}$ & $240 \mathrm{a}$ \\
Jun 30 & $179 \mathrm{a}$ & $200 \mathrm{~b}$ & $166 \mathrm{a}$ & $258 \mathrm{a}$ \\
Jul 30 & $190 \mathrm{a}$ & $248 \mathrm{a}$ & $133 \mathrm{~b}$ & $181 \mathrm{~b}$ \\
Aug 30 & $70 \mathrm{~b}$ & $87 \mathrm{c}$ & $107 \mathrm{~b}$ & $186 \mathrm{~b}$ \\
Sep 30 & $58 \mathrm{~b}$ & $69 \mathrm{c}$ & $127 \mathrm{~b}$ & $200 \mathrm{~b}$ \\
& & & & $30 \mathrm{~d}$ \\
May 30 & Mean Tiller Weight ${ }^{2}(\mathrm{mg})$ & $189 \mathrm{c}$ \\
Jun 30 & $311 \mathrm{~cd}$ & $137 \mathrm{~d}$ & $162 \mathrm{~b}$ & $527 \mathrm{~b}$ \\
Jul 30 & $399 \mathrm{bc}$ & $300 \mathrm{bc}$ & $291 \mathrm{~b}$ & $435 \mathrm{~b}$ \\
Aug 30 & $237 \mathrm{~d}$ & $173 \mathrm{~cd}$ & $614 \mathrm{a}$ & $812 \mathrm{a}$ \\
Sep 30 & $525 \mathrm{~b}$ & $467 \mathrm{ab}$ & $492 \mathrm{a}$ & $505 \mathrm{a}$ \\
\hline
\end{tabular}

${ }_{1}^{1}$ Numbers within columns with the same letter are not significantly different, $\mathrm{P}>0.10$.

${ }^{2}$ The month by grazing history by year interaction for mean tiller weight was significant at $\mathrm{p}=0.021$. term precipitation is $560 \mathrm{~mm}$ compared to $340 \mathrm{~mm}$ at the PER.

Mean tiller weights increased about $117 \%$ on current-year-deferred macroplots and about $175 \%$ on long-term-rested macroplots each year during the month in which measurable declines of live tiller densities occurred (Table 1). Tiller densities were unchanged and mean tiller weight continued to increase the remainder of the growing season in both years. Stable late-summer tiller densities are consistent with other studies which indicate about $80 \%$ of prairie sandreed tillers emerge by mid-June after which emergence generally remains low the remainder of the growing season (Hendrickson et al. 2000). End-of-season tiller densities increased $91 \%$ from 1989 to 1990 on current-year-deferred macroplots compared to $142 \%$ on long-term-rested macroplots (Table 1). Higher end-of-season densities and mean weights of live tillers on longterm-rested compared to current-yeardeferred macroplots in 1990 are indicative of relatively high levels of plant vigor commonly observed in prairie sandreed in high seral plant communities in this area.

\section{Rhizomes}

Monthly rates of change in the density of differentiated buds that could produce rhizomes were similar for grazing histories except during July and August when bud density on long-term-rested macroplots increased by about 1.6 buds $\mathrm{m}^{-2}$ day $^{-1}$ compared to 0.3 buds $\mathrm{m}^{-2}$ day $^{-1}$ on currentyear-deferred macroplots (Fig. 2). This pattern was consistent over years regardless of precipitation regime. Corresponding delays in differentiation of rhizome buds (Nixon 1993) and herbage production (Table 1) during May on long-term-rested compared to current-year-deferred macroplots indicated litter accumulation on rested sites may have reduced soil temperatures (Willms et al. 1993). Mean densities of buds for grazing histories in May 1990 were similar to densities in September 1989 indicating most of the rhizome buds in September survived into the subsequent year. End-of-season bud densities for grazing histories were similar in 1989 , but $52 \%$ higher on long-termrested than current-year-deferred macroplots in September 1990 when near average precipitation occurred (Nixon 1993).

The relationship between total weight and length of new rhizomes was highly predictable $\left(\mathrm{R}^{2}=0.90\right)$ regardless of the month or year of sampling (Fig. 3). Mean biomass ranged from $6.4 \mathrm{~g} \mathrm{~m}^{-1}$ with $52 \mathrm{~cm}$ 


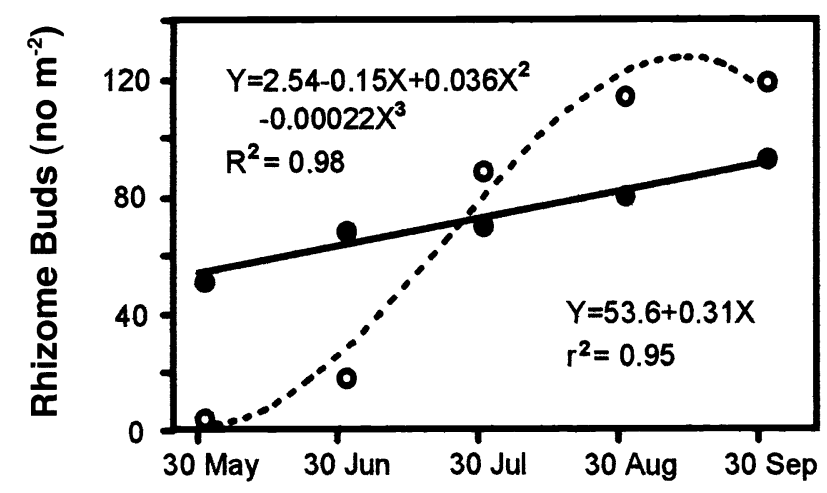

Fig. 2. Seasonal patterns in the density of differentiated buds on vertical rhizomes below crowns of prairie sandreed that could produce new rhizomes ( $x=$ days after 30 May) from May through September on long-term-rested $(O)$ and current-year-deferred $(\bullet)$ macroplots at the University of Nebraska, Panhandle Experimental Range.

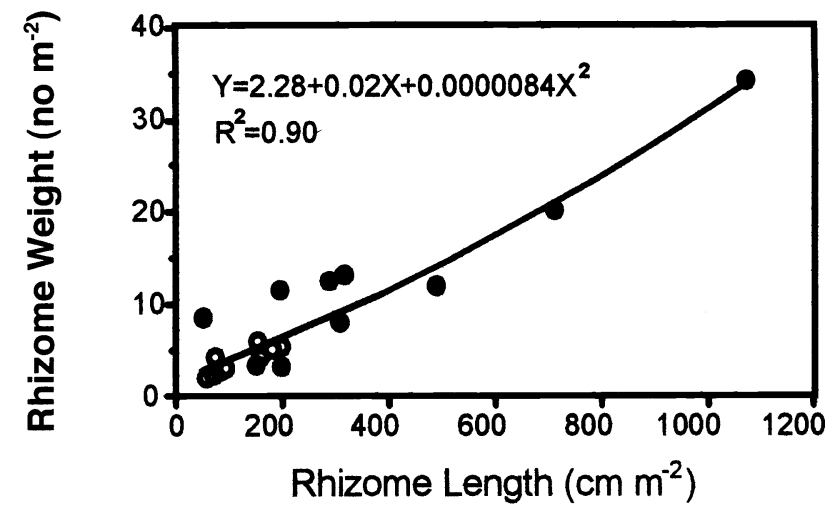

Fig. 3. The relationship between total weight and total length of new prairie sandreed rhizomes from May through Sept. $1989(O)$ and $1990(\bullet)$ at the University of Nebraska, Panhandle Experimental Range. $\mathrm{m}^{-2}$ to $3.1 \mathrm{~g} \mathrm{~m}^{-2}$ with $1073 \mathrm{~cm} \mathrm{~m}^{-2}$ (Fig. 3). About $94 \%$ of the reduction in mean biomass per unit length occurred within the first $20 \%$ of the observed range in total length. Mean biomass was about $3.3 \mathrm{~g} \mathrm{~m}^{-2}$ when length of new rhizomes reached 200 $\mathrm{cm} \mathrm{m} \mathrm{m}^{-2}$. After soil moisture deficits induced reductions in total length of new rhizomes during July 1989 (Fig. 4), mean biomass per unit length was $82 \%$ greater on current-year-deferred macroplots and $49 \%$ greater on long-term-rested macroplots (Fig. 3) indicating low-weight rhizomes may have senesced more frequently than heavy rhizomes. Additionally, remaining intact rhizomes may have received proportionately greater amounts of carbohydrates from shoots (Welch 1968) or carbohydrates may have been translocated from senescing rhizomes into intact rhizomes (Jónsdóttir and Callaghan 1990). Carbohydrate concentrations in prairie sandreed rhizomes generally increase rapidly during late summer (Welch 1968). However, little change occurred in mean biomass per unit length when rapid rhizome growth occurred during August and September 1990 (Fig. 3 and 4).

Length of old rhizomes within excavated sample volumes was a significant linear covariate in the analysis of tiller density, herbage, and density of buds that could produce rhizomes. Water and/or nutrients may be translocated from old non-assimilating tillers to connected tillers with live shoots (Jónsdóttir and Callaghan 1988). In contrast, length and weight of new rhizomes were not affected by length of old rhizomes. This contrasts with highly sig- nificant linear relationships between preceding and current-year rhizome biomass for herbaceous species in temperate environments (de Kroon et al. 1992). However, based on the number of interconnected crowns and assuming 1 crown per year, old rhizomes may have been as much as 7 years old in our study. While crowns may produce more than 1 rhizome in a single year, only 1 crown has developed at the distal end of rhizomes per year in our preliminary field studies of plants grown in containers. Additionally, a percentage of preceding-year rhizomes may have been included in the new rhizome category if color and scale condition criteria were met. Growth of new prairie san- dreed rhizomes after buds differentiated appeared to be primarily dependent upon resources from assimilating tillers.

The limiting effects of soil moisture deficits on length of new rhizomes in 1989 were uniformly profound regardless of grazing history (Fig. 4). Tiller weights increased from July to September (Table 1) with no change in length of new rhizomes and no difference in rhizome length between grazing histories (Fig. 4) in September. However, when average precipitation occurred in 1990, length of new rhizomes at the end of the growing season was 3.4 times greater for long-term-rested than current-year-deferred macroplots (Fig. 4). Density and mean weight of live

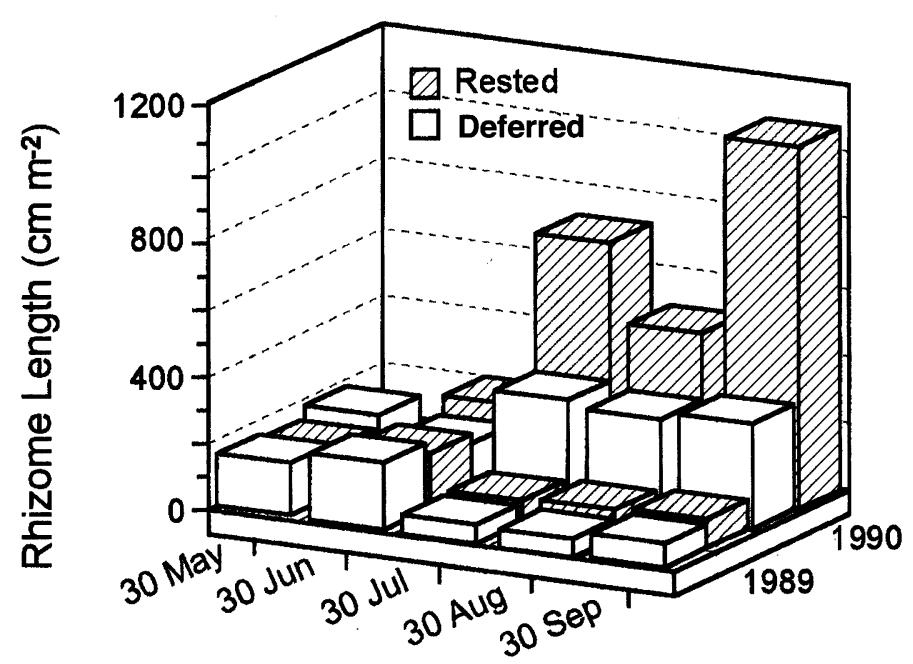

Fig. 4. Mean total length of new prairie sandreed rhizomes at 30-day intervals during the growing season on long-term-rested and current-year-deferred macroplots at the University of Nebraska, Panhandle Experimental Range. 


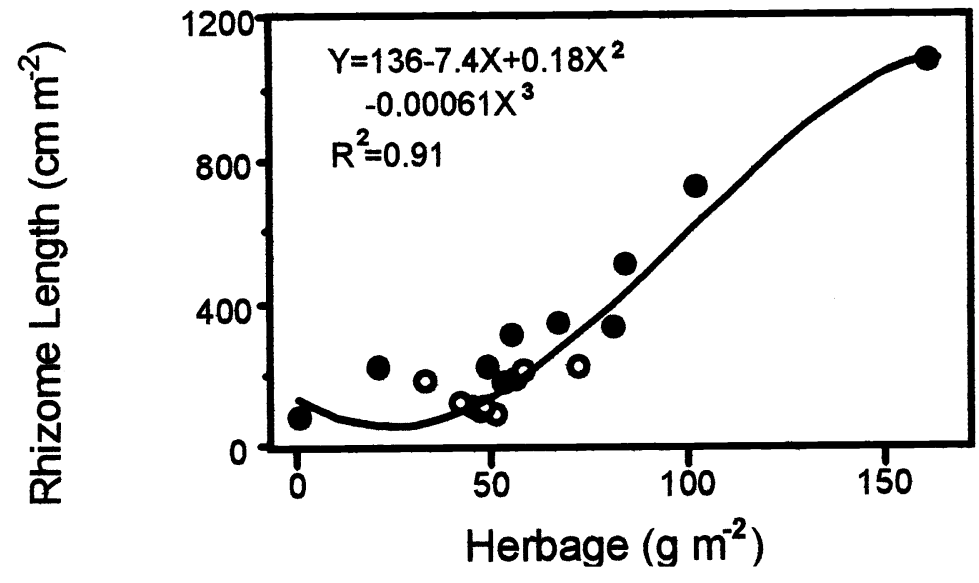

Fig. 5. The relationship between total length of new rhizomes and total live herbage of prairie sandreed from May through Sept. $1989(\bigcirc)$ and $1990(\bullet)$ at the University of Nebraska, Panhandle Experimental Range.

tillers in late September were both about $60 \%$ higher on rested than on deferred macroplots in 1990 (Table 1) resulting in a mean of 10.7 in of new rhizomes per $1.0 \mathrm{~m}^{2}$.

Lack of correlation between length of new prairie sandreed rhizomes and tiller density was similar to Carex bigelowii (Wikberg et al. 1994) which also exhibits epic events of tiller mortality. In contrast, live herbage of prairie sandreed accounted for $91 \%$ of the variation in new rhizome length regardless of grazing history or the year or month of sampling (Fig. 5). The relationship between total length of new rhizomes and mean tiller weight was similar to, but less predictable $\left(\mathrm{R}^{2}=0.76\right)$ compared to total live herbage (Nixon 1993). Therefore, we accept our hypothesis that the relationship between rhizome length and live herbage is not affected by grazing history. The lack of grazing history effects is consistent with studies of Carex bigelowii on subarctic rangeland (Jónsdóttir 1991). Strong relationships between total live herbage and length of new rhizomes have also been reported for forbs Aster lanceolatus and Solidago canadensis (Schmid et al. 1995) and Paris tetraphylla (Hara and Wakahara 1994).

During both years, measurable increases in total length of new rhizomes did not occur until herbage exceeded a threshold of about $50 \mathrm{~g} \mathrm{~m}^{-2}$ (Fig. 5) which may correspond to the 4 to 5 leaf stage after which Brejda et al. (1989) reported initiation of new rhizome growth. Beyond this threshold, increases in rhizome length per unit of herbage were highest, about $10 \mathrm{~cm} \mathrm{~g}^{-1}$, near $100 \mathrm{~g} \mathrm{~m}^{-2}$ (Fig. 5). Increases in rhizome length per unit of live herbage were about $40 \%$ lower when live herbage was near 50 and $150 \mathrm{~g} \mathrm{~m}^{-1}$ (Fig. 3 and 5).
Therefore we reject our hypothesis that length of new prairie sandreed rhizomes increases at a constant rate as the mass of live herbage increases.

Precipitation regime by grazing history interaction effects on herbage production were pronounced; however, the relationship between live herbage and length of new prairie sandreed rhizomes was independent of precipitation, grazing history, or excavation date indicating a wide population of inference for the results of this study. Measurable increases in rhizome length in a given year may increase the potential for herbage production if the percentage of tillers originating from relatively long rhizomes increases (White 1977 Brejda et al. 1989) and/or access to limited soil nutrients increases. Interaction between grazing history and precipitation in this study indicates availability of soil moisture will control the extent to which potential herbage production is expressed in semiarid environments.

Prairie sandreed is a mid- and late seral species capable of producing relatively large amounts of herbage critical for ecosystem functions and livestock production. Reproduction of this species is almost exclusively vegetative from crowns formed at the distal end of rhizomes (Brejda et al. 1989, Cullan et al. 1999). Clonal growth into surrounding areas without prairie sandreed and its ability to survive burial on disturbed sites are important processes in secondary succession (Weaver 1965, Maun and Perumal 1999). Consequently, the occurrence of a live-herbage threshold for rapid growth of rhizomes should be considered when developing grazing management strategies designed to increase the composition of this species. Heavy defoliation during the growing season before threshold levels of herbage have been produced would preclude measurable increases in the composition of prairie sandreed in most years, regardless of grazing systems. The likelihood of producing enough herbage for rapid rhizome development after heavy defoliation in summer-grazed pastures, declines as the growing season progresses and/or precipitation declines (Reece et al. 1999).

Deferring grazing until seedheads have emerged in August would improve the potential for increasing the composition of prairie sandreed (Reece et al. 1996). Tillers that develop from the longest prairie sandreed rhizomes are generally the largest and most likely to produce seedheads (White 1977). Nutritive value and palatability of reproductive tillers to beef cattle decline when seedheads emerge (Reece et al. 1999). These relatively large and generally ungrazed tillers may be critically important for grazing resistance in prairie sandreed by translocating nutrients to connected vegetative tillers (Jónsdóttir and Callaghan 1990, Cullan et al. 1999) that continue to be highly palatable through the summer grazing season (Northup 1993). Given the relatively high preference by cattle for prairie sandreed (Northup 1993, Cullan et al. 1999), periodic or repeated full growing season deferment may be the only reliable method of obtaining measurable increases in prairie sandreed populations. On sites where cool-season graminoids produce 20 to $50 \%$ of the herbage, heavy grazing of cool-season species in April, before prairie sandreed tillers emerge, may enhance this species response to full growing-season deferment (Reece et al. 1999).

\section{Literature Cited}

Brejda, J.J., L.E. Moser, and S.S. Waller. 1989. Rhizome and tiller development of three Nebraska Sandhills warm-season grasses. p. 211-215. In: T. B. Bragg and J. Stubbendieck (eds.) Proc. Eleventh North Amer. Prairie Conf Lincoln, Nebr.

Callaghan, T.V. 1976. Growth and population dynamics of Carex bigelowii in an alpine environment: strategies of growth and population dynamics of tundra plants 3 . Oikos 27:402-413.

Cullan, A.P., P.E. Reece, and W.H. Schacht. 1999. Early summer grazing effects on defoliation and tiller demography of prairie sandreed. J. Range Manage. 52:447-453.

Dahl, B.E. 1963. Soil moisture as a predictive index to forage yield for the sandhills range type. J. Range Manage. 16:128-132. 
de Kroon, H., T. Hara, and R. Kwant. 1992. Size heirarchies of shoots and clones in clonal herb monocultures: do clonal and nonclonal plants compete differently? Oikos 63:410-419.

Great Plains Flora Association. 1986. Flora of the Great Plains. T.M. Barkley (ed.). University Press Kansas. Lawrence, Kan.

Hara, T. and M. Wakahara. 1994. Variation in individual growth and the population structure of a woodland perennial herb, Paris tetraphylla. J. Ecol. 82:3-12.

Hartnett, D.C. 1989. Density- and growth stage-dependent responses to defoliation in two rhizomatous grasses. Oecologia. 80:414-420.

Hartnett, D.C. 1990. Size-dependent allocation to sexual and vegetative reproduction in four clonal composites. Oecologia 84:254-259.

Hendrickson, J.R., L.E. Moser, K.J. Moore, and S.S. Waller. 1998. Morphological development of 2 warm-season grasses in the Nebraska Sandhills. J. Range Manage. 51:456-462

Hendrickson, J.R., L.E. Moser, and P.E. Reece. 2000. Tiller recruitment patterns and biennial tiller production in prairie sandreed. J. Range Manage. 53:537-543.

Jónsdóttir, I.S. 1991. Effects of grazing on tiller size and population dynamics in a clonal sedge Carex bigelowii. Oikos 62:177-188.
Jónsdóttir, I.S. and T.V. Callaghan. 1988. Interrelationships between different generations of interconnected tillers of Carex bigelowii. Oikos 52:120-128.

Jónsdóttir, I.S. and T.V. Callaghan. 1990. Intraclonal translocation of ammonium and nitrate nitrogen in Carex bigelowii Torr. ex Schwein. using ${ }^{15} \mathrm{~N}$ and nitrate reductase assays. NewPhytol. 114:419-428.

Makita, A. 1996. Density regulation during the regeneration of two monocarpic bamboos: self-thinning or intraclonal regulation? J. Vegetation Sci. 7:281-288.

Maun, M.A. and J. Perumal. 1999. Zonation of vegetation on lacustrine coastal dunes: effects of burial by sand. Ecol. Letters 2:14-18.

Nixon, J.L. 1993. Dynamics of prairie sandreed rhizome development. M.S. Thesis. Univ. Nebraska. Lincoln, Nebr.

Northup, B.K. 1993. Utilization of native forages of the Nebraska Sandhills by yearling cattle. Ph.D. Diss. Univ. Nebraska. Lincoln, Nebr.

Reece, P.E., T.L. Holman, and K.J. Moore. 1999. Late-summer forage on prairie sandreed dominated rangeland after spring defoliation. J. Range Manage. 52:228-234.

Reece, P.E., J.E. Brummer, R.K. Engel, B.K. Northup, and J.T. Nichols. 1996. Grazing date and frequency effects on prairie sandreed and sand bluestem. J. Range Manage. 49:112-116.
SAS. 1986. SAS/STAT users guide. Release 6.03. SAS Inst., Inc., Cary, N.C.

Schmid, B., F.A. Bazzaz, and J. Weiner. 1995. Size dependency of sexual reproduction and clonal growth in two perennial plants. Can. J. Bot. 73:1831-1837.

Searle, S.R., F.M. Speed, and G.A. Milliken. 1980. Populations marginal means in the linear model: an alternative to least squares means. Amer. Statistician 34:216-221.

Weaver, J.E. 1965. Native vegetation of Nebraska. Univ. Nebraska Press. Lincoln, Nebr.

Welch, T. G. 1968. Carbohydrate reserves of sand reedgrass under different grazing intensities.J. Range Manage. 21:216-220.

White, L.M. 1977. Perenniality and development of shoots of 12 forage species in Montana. J. Range Manage. 30:107-110.

Wikberg, S., B.M. Svensson, and B.A. Carlsson. 1994. Fitness, population growth rate and flowering in Carex bigelowii, a clonal sedge. Oikos 70:57-64.

Willms, W.D., S.M. McGinn, and J.F. Dormaar. 1993. Influence of litter on herbage production in the mixed prairie. $\mathrm{J}$. Range Manage. 46:320-324. 